\title{
Arabize: Localization Project Management
}

\author{
Sherif Masoud ${ }^{1}$ and Ali H. Awni ${ }^{2}$ \\ ${ }^{1}$ American University in Cairo, Egypt \\ ${ }^{2}$ Department of Management, School of Business, American University in Cairo, Egypt
}

\begin{abstract}
This case deals with project management at Arabize, a leading localization company in the Middle East. It describes the company, its customers, competitors, services, competitive advantage and resources. It then sheds light on the project lifecycle, with its order, production, QC and delivery phases. The core business of the company consists of localization projects. The main challenge is to proactively yet economically make skilled human resources available for new projects. In the past years, Arabize used freelancers to complement its internal resources. In many cases freelancers cost is higher than the cost of internal resources, in addition to the extra risk associated with availability and control of those external resources. Top Management is seriously considering other options to ensure that the required skilled human resources are available for projects.
\end{abstract}

Keywords: Project management, localization.

\section{Introduction ${ }^{1}$}

In early November 2010, Manal Amin, Founder and CEO, and Ebtihal Taha, Operations Director of Arabize, were holding a meeting to discuss how to restructure the company operations to achieve better business results. Their biggest challenge was developing strategic plans to ensure the undisrupted availability of resources needed for future Arabize projects in the most economical way. Given the often hard-toanticipate fluctuation of Arabize project requirements, it is tough to be ready for new projects while minimizing total project costs. It takes nine to twelve months to develop a new hire into a staff member that is capable of delivering localization project tasks up to the international standards adhered to by Arabize.

${ }^{1}$ Unless stated otherwise, all information in this case is based on interviews with top management and staff of Arabize, conducted during the period from August 2010 to December 2010.
In the recent years, Arabize has maintained the full time employment of the minimum required human resources and acquired the services of external freelancers as needed for new projects. Due to the unique skills sought, those freelancers have been almost always former Arabize employees. Using freelancers comes with many risks that could occur throughout the project life cycle, such as the difficulty to control freelancers and data security problems. Therefore, Amin and Taha were discussing different options for ensuring the availability of localization project resources proactively yet economically.

\section{Localization}

Rapid globalization of information systems resulted in the widespread expansion of software and information related products in many countries. This triggered the need for software and content "localization" as a necessity for selling in the different countries

Copyright (C) 2012 Sherif Masoud and Ali H. Awni. This is an open access article distributed under the Creative Commons Attribution License unported 3.0, which permits unrestricted use, distribution, and reproduction in any medium, provided that original work is properly cited. Contact author: Ali H. Awni E-mail: ahawni@aucegypt.edu 
with different cultures and conventions. Software and content developers often underestimate the level of effort and attention to details required to create products for different markets with different language editions.

Microsoft (Microsoft website, 2012) identified two facets for the process of creating internationalized software: Worldreadiness, which covers generic coding and design issues and comprises two major areas-globalization and localizability; and localization, which involves translating and customizing a product for a specific market. Software Localization is more than the translation of a product's User Interface. Companies localize software in order to overcome cultural barriers for their products to reach a much larger target audience.

The distinction between internationalization and localization is subtle but important. Internationalization is the adaptation of products for potential use virtually everywhere, while localization is the addition of special features for use in a specific locale. Internationalization is done once per product, while localization is done once for each combination of product and locale. The processes are complementary, and must be combined to lead to the objective of a system that works globally (Software localization, Wikipedia, 2012).

Software localization is the process of adapting a software product to the linguistic, cultural and technical requirements and conventions of a target market (SDL, 2012). Cultural conventions include the use of various writing systems, sort orders, different formats for date, time, numbers, and currency, and different keyboard layouts. A software product that has been localized properly has the look and feel of a product originally written and designed for the target market. Some of the points that have to be considered, as well as the language, in order to effectively localize a software product or website are: measuring units, number formats, address formats, time and date formats (long and short), paper sizes, fonts, default font selection, case differences, character sets, sorting, word separation and hyphenation, local regulations, copyright issues, data protection, payment methods, currency conversion, taxes. For issues and methods related to software locations, please refer to Collins (2002).

The localization process is labor-intensive and often requires a significant amount of time from the development teams. Localization projects often run in parallel with the development of the original product to enable simultaneous shipment of all language versions. Sometimes, localization can be attempted after the original product version is released as conditions of sales (typically a large deal) to another market. A localization project involves, in addition to translation, other activities such as software testing and desktop publishing.

Small localization companies, such as ARABIZE, can provide higher quality of work pertaining to a specific language. Some large international global software developers, such as Microsoft, prefer to deal with Multiple Language Vendors (MLV), large localization companies that provide project management for localization services in required languages, than dealing with many smaller localization companies with deeper expertise in limited languages. MLVs usually outsource the localization of specific languages to smaller firms such as ARABIZE.

A small number of industry players; such as SAP, ORACLE, Microsoft, IBM and HP; make up a large part of the size of the market for localization services. With that comes the leverage and power to squeeze the margins of localization service providers.

\section{Overview of Arabize, Customers and Services}

Manal Amin founded Arabize in 1994 as an independent, privately-held service company located in Egypt. It was established to meet the market need for professional Arabic 
localization services of the highest standards. Today, Arabize is a leading localization company in the Middle East; helping several international organizations extend their product distribution to new markets (Arabize website, 2012).

Arabize headquarters occupies $1,200 \mathrm{~m}^{2}$ of office space, with infrastructure capable of supporting 120 employees. The infrastructure includes CAT 5 Network infrastructure; Microsoft Network Model; Internet bandwidth of $2 \mathrm{Mbps}$ CIR; FTP server and PCs of minimum dual core $2.8 \mathrm{GHz}$, 1GB Ram, 80 GB HDD and 17" Monitor. Arabize information systems are protected from viruses by the latest technologies in the field.

People are Arabize's most valued asset; they are the core of what makes Arabize unique and successful. The staff represents a broad spectrum of people with diverse backgrounds and experience. Arabize also maintains a pool of professional freelancers to support the work of the Language, Content, Web Solutions and DTP Departments. Under the banner Arabize, the company combines to form a strong professional team with one common aim. The organization chart of Arabize is shown in Figure 1. This chart focuses on the restructuring underway to streamline operations and enable better project management. While Arabize work spans diverse fields, one of the biggest achievements at Arabize is the development of Financial Corpus, a translation memory in which the terms in financial projects translated in Arabize for ten years were collected.

The proven quality of Arabize services makes the company the first choice for many leading international companies, either directly, such as Oracle and SAP, or indirectly through multi-lingual vendors, such as Microsoft, SUN Microsystems, Toshiba, Cisco, Canon and HP. Arabize has two main competitors in the Middle East.

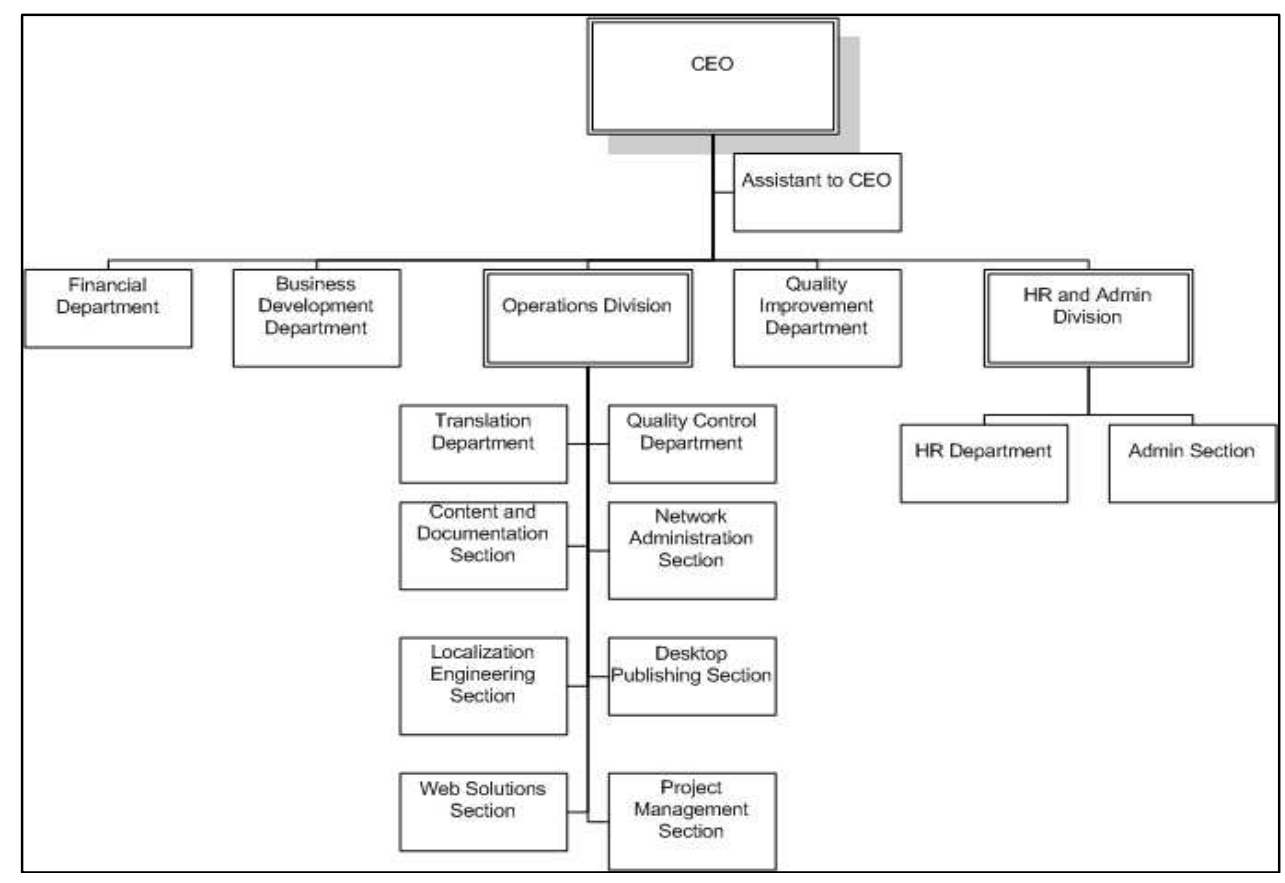

Figure 1. Arabize Organization Chart 
The portfolio of services offered by Arabize is shown in

Figure 2. Most customers are outside Egypt and the biggest two are Oracle and SAP. There are two types of customers: direct and multi-lingual vendors (MLVs). For example, Microsoft directly awards the localization of Windows and Office only, but it awards the rest of its products through MLVs. It is worth mentioning that most if not all customers are quite satisfied with their business relationship with Arabize. As quoted by Claire Dyens, Senior Manager, Oracle
Worldwide Product Translation Group: "Arabize has been an Oracle certified vendor for Arabic translations for more than 10 years. Our relations are a perfect illustration of a trustful partnership, which is an essential cornerstone of our business. Arabize delivers a top class service, meeting all expectations in terms of quality, timeliness and cost-effectiveness. We look forward to maintaining this successful collaboration!" (Arabize website, customers' testimonials, 2012).

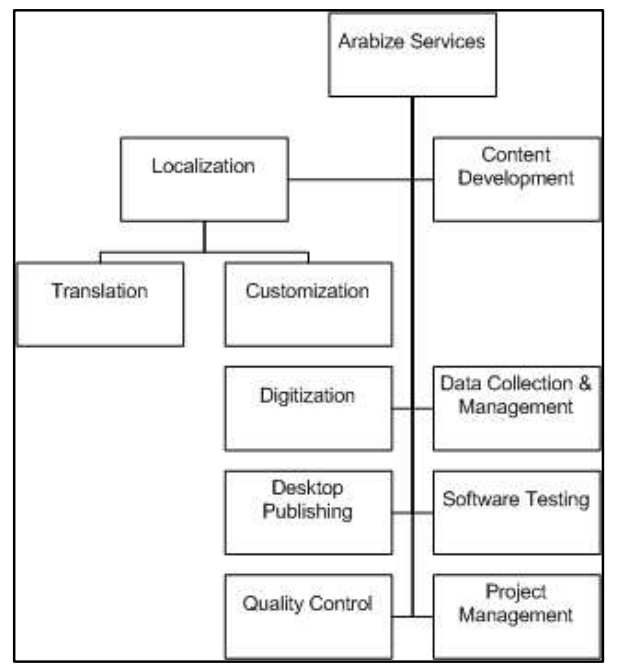

Figure 2. Arabize Services

Over the years, Arabize service structure has developed in parallel with both expanding markets and technological advancements. Today, Arabize portfolio of services includes:

- Localization deals with more than simply translating words into the target language of a locale. Localization involves translating and modifying websites, software and documentation into the specific language style that the target audience is most comfortable with, and it is also concerned with ensuring that product content, style, graphics and cultural conventions-such as currencies, dates and units of measurementare appropriate to the country and language in which it is to be used. In other words, localization is the sum of translation plus customization that is required to create a different language edition of a product in order for it to work successfully in a particular locale or country. All text needs to be displayed in the native language and native conventions must be used for sorting and formatting. For example, a word processing program may require the addition of a new spellchecker that recognizes words in the local language. The goal of localization is to create a product that looks and feels as though it was created in the target country or market. Arabize specializes in the localization of user interfaces; user assistance printed and on-line documentation (user guides, manuals and tutorials); computer-based training and e-learning material; websites 
and web applications; marketing literature; legal documents and life science materials.

- Content Development includes technical writing, copywriting and copyediting. Arabize provides this service in highquality, international standards of content in Arabic, English and German. Either working from scratch, or developing an existing document, Arabize expert documentation team provides customers with content for websites, training courses, technical manuals and marketing materials. Arabize documentation specialists work closely with experts from other departments to ensure the best possible results. Arabize experience and skills in researching, writing, organizing, collating information and editing enables the development and production of written content that is specifically customized to suit customers' needs. Some of Arabize's most popular productions include fact sheets, quick reference guides, user guides, reference guides, setup guides, administration guides, operational guides, online help and web help pages and websites.

- Digitization involves the transformation of manuscripts and books into digital formats-either via scanning or data entrythat can be published on portals and websites. The rapidly growing demand for Arabic content on the Internet has made digitization an increasingly important service in recent years.

- Data Collection and Management are disciplines that require precise attention to detail. Arabize skilled team accurately designs data-collection questionnaires (online and print), collates collected data and information and verifies collected information. Arabize also edits, structures, organizes and enter content derived from the collected data to content management systems (CMS) and/or portals.

- Desktop Publishing: The experts in Arabize Desktop Publishing (DTP)
Department specialize in designing and editing graphics for all kinds of documents, with meticulous attention paid to quality and accuracy, whatever the type, size or source of original documents.

- Software Testing: To maintain consumer trust and loyalty, all bugs and defects that may be contained within software must be identified and corrected before the product finds its way into the hands of the end user. Arabize team of specialists meticulously tests the functionality, the graphical user interface (GUI) and the layout of every product.

- Quality Control (QC): Arabize Quality Control Department maintains, develops and guarantees general quality by deploying the best qualified specialists in the localization sector. Arabize production Department work closely with the QC Department to provide maximum efficiency and value for both Arabize customers and the organization. The QC Department also conducts the same service for external customers.

- Project Management: Every project that Arabize undertakes is professionally coordinated by a project manager. This provides the customers with the highest standards of service regarding efficiency and quality.

\section{The Project Lifecycle}

The localization process is a reasonably mature industry, with relatively standard production outsourcing framework that localization service providers follow. Furthermore, the use of computer-aided translation tools is pretty standard (Asnes, 2009). The process starts with segmenting the text into sentences, to be presented in a convenient way to the translator/localizer. The translation and the source text are saved in the translation memory for reuse in future translations. Also a terminology glossary lookup is implemented to ensure same definitions are used across. The use of those 
tools ensures translation consistency and uniformity, and reduces localization cost and time due to reuse of previous translations. The main challenge in managing a localization project is ensuring the availability of the required skilled human resources.

The project lifecycle at Arabize is depicted in Figure 3. This section describes the activities associated with every phase of the project.

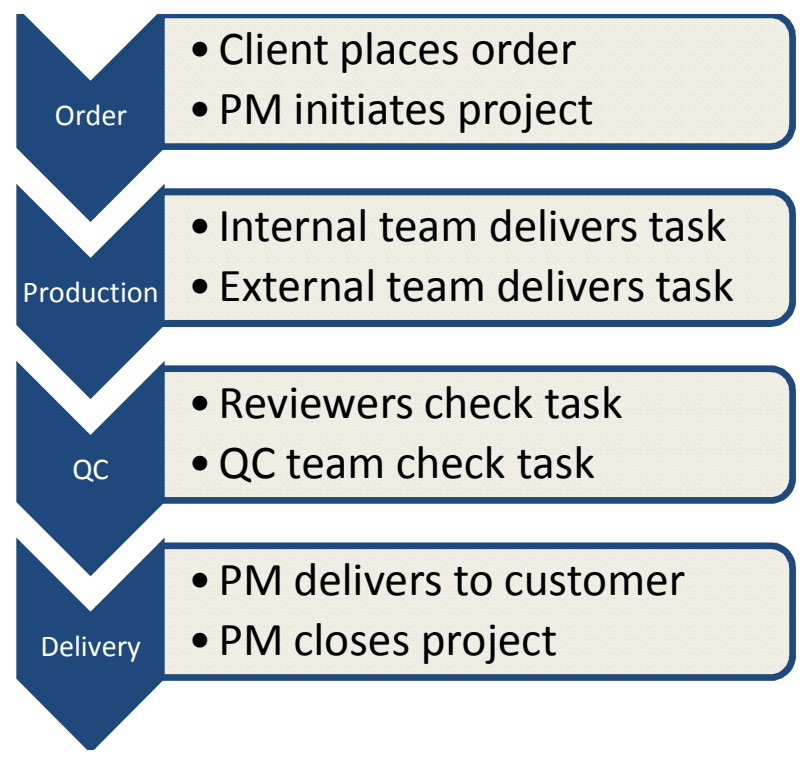

Figure 3. The Project Lifecycle

\section{Order}

As soon as a notification is received from the customer, the project manager starts initiating the project internally at Arabize. The project manager coordinates with Arabize Translation Department manager and section heads to select project resources based on the availability of localizers and their skill levels, which are documented and updated continually. AlMudir workflow system shows the availability of localizers, who are booked on a first-come-first-served basis. Project resources selection factors include experience and time frame. The project manager divides the project into batches, e.g. 5000 words to 5 batches, and then the status is monitored per batch. The project start date depends on the release of the product English version, as it should be available before the translation/localization starts. There is an alias email that is included in project communications, an alias is set for each customer including the PM(s) handling the project and the backup PM(s). Currently, a new system is needed to allow the project manager to monitor the progress of work without inputs from the working resources. While the above description refers only to the Language production team, the same cycle also applies to the other project types, such as Content and DTP.

The project manager arranges the project kick-off meeting. AlMudir workflow system is used from the outset of the project. The interface of AlMudir Project Manager-Home and AlMudir Project Manager-Project are depicted in Figures 4 and 5, respectively. The project is created and resources are requested and assigned on the system. The project manager allocates resources from other sections or freelancers if needed. The decision of freelancer outsourcing occurs based on the project need and available experience and resources. Freelancers are 
selected based on commitment, quality and experience. The freelancer database includes both individuals and smaller companies (subcontractors) and is constantly updated. In the past years, freelancers cost more than internal resources. In some cases, freelancers cost is not different from internal resources. The project manager negotiates with the customer for time extensions as necessary. Some time reserve is left for unforeseen events.

\section{Production}

During the production phase, the project manager ensures any issues are managed on a case-by-case basis. For example, actions are planned as necessary to compensate for time lost if needed. The project manager ensures the project progresses as planned. Sometimes customers' instructions are not accurate, and open issues in project are tracked by email. There are regular conference calls with the customer's language specialist, project manager, vendor manager (customer representative) with minutes of meeting.

When the translator presses "start" on the AlMudir system, time starts counting while they carry out their tasks. The Language Section Head finally records comments and signs off and also records a project diary with positives and negatives. The customer provides references on technical subjects, such as explaining the product. If difficult terms are encountered by Arabize translators, the customer is consulted. Glossaries from old work are also consulted. Production tasks are often carried out on remote customer servers, which is challenging because of continual monitoring by the customer and effect of internet connection reliability issues. Some problems occur, such as the file will not open, and in this case the help of localization engineer is necessary.

\section{Quality Control (QC)}

The Translation section head reviews and checks the tasks done by translators and reviewers before the $\mathrm{QC}$ team performs the usual linguistic inspection activities. Then the findings are recorded on the AlMudir system. AlMudir tracks the performance of every localizer and reviewer. Customer complaints are also recorded on the system so that the QC team performs the related investigation cycle. In SAP projects, quality activities include applying QETT (Quality Evaluation Tool for Translation), which is the linguistic sign-off required by SAP, as well as internal QC sheets. The QC function is also responsible for updates of SAP support package.

\section{Delivery to the Customer}

To illustrate localization project deliverables, an item is shown before and after localization to Arabic in Figures 6 and 7, respectively. The project manager is responsible for delivering to the customer, getting the customer's feedback and closing all open points with the customer. The PM delivers the project files after ensuring they open normally and generally there are no technical issues with them and all customer requirements were met. The Project Management Section Head signs all invoices after review. Delivery notes that contain open issues at delivery time are transferred to the customer. Post-mortem report is initiated by PMs after the project delivery. It includes information about best practices and problems with customer/lessons learned.

The project manager ensures that the project backup activity occurs daily, weekly and/or at the end of a project. If the project period is less than one week, the team leader saves the project files locally on his/her PC (Daily). If the project period is more than one week, the project manager instructs the backup operator to back up the project (Weekly). At the end of each project, the project manager saves the whole project on the backup server and notifies the backup operator of the project's location on the backup server. Between 60 to 90 days after a project's 
completion, the backup operator saves the backup on tapes. After a minimum of three months, the project manager clears the project folder located on the network and keeps only the deliverables on the backup server.

\section{Competitive Advantage}

In response to the growing demand for localization services in the Middle East and North Africa (MENA) market, Arabize offers premium quality localization services in the target languages of Arabic, English and German. In the MENA region there are many variations in dialect, law, currency, etiquette, customs, and business practices. Despite this, Arabize has learned how to create high quality Arabic language products that cover the whole region by using a standard Arabic that is recognized by all as proper Arabic and can be used without detriment to individual dialects or cultures. Standard Memory Tools (e.g. glossary) allow memorizing human translators' work and thus ensure consistency in translation.

It is a common misconception that the process of "localization" is nothing more than that of translation. Since founding Arabize, it has been Amin's mission to correct this misconception and awaken awareness about the importance of localization. She has trained her staff in order to give them the tools they need to do the job, and has developed working standards and criteria that encourage successful growth. Her dedication and experience has taught her that to do any job well all aspects of the task must be done the right way. It is that simple logic which enables her pursuit of excellence. When asked to describe her professional mindset she quotes Winston Churchill's words: "I am easily satisfied with the very best."

It is the professional skills in this discipline that has made Arabize the international success that it is today. As the company grows, so does its reputation for quality work, unrivalled attention to detail, and the highest levels of individual attention and service. In keeping with the commitment to top quality services, Arabize has implemented the most rigorous quality assurance processes, achieving official ISO 9001:2000 certification in 2005 as well as the European standard EN15038:2006 translation certification. Furthermore, more than 30 Arabize localizers are Certified Localization Professionals (CLP) by The Institute of Localization Professionals (TILP), Ireland.

Arabize uses dedicated Project and Translation Teams. This ensures consistency from project to project and increases speed and accuracy. All Arabize linguists are university graduates and professional specialists in their language pairs (e.g, English and Arabic). Arabize specialists in each field undertake glossary development to guarantee consistent quality. Arabize provides a complete and automated project management service at every step of a project; from the initial enquiry to the final delivery. All Arabize translators are highly qualified, culturally aware native-speakers of the target language that customers need. All Arabize employees are constantly honing their skills through both in-house and external training. Arabize has an independent Quality Assurance Department to guarantee the services are always of the highest caliber.

\section{Current Challenges Facing the Organization}

Localization is a knowledge-based service that depends heavily on the human element. The competitiveness of localization services providers, such as ARABIZE depends on their ability to attract and retain talented people. The limited supply of skilled people, aggravated by the growth of the industry and increased competition, is further complicated by the fact that the necessary quality and skills required takes years to develop (Cyr and Lew, 2003). Competition for the skilled human resources is not just from other competing localization companies, but also from translation services at large. 
During the meeting, Amin and Taha acknowledge that "although Arabize currently handles all of its projects successfully, there are challenges that required certain strategies to overcome them." First, Amin remembers that during the early start, Arabize had only one customer, Lotus. Later on, when IBM acquired Lotus, Arabize lost its business with Lotus. This was a really big challenge, and the lesson learned at that time was the urgent need to diversify the customer base. Subsequently, diversifying the customer base led to adopting a high degree of flexibility in project selection. In other words, Arabize went on to accept almost all projects it had a chance to get. This in turn led to the need for continual human resource-acquisition and development. Since it was difficult to forecast the load of accepted projects, Arabize had to depend on freelancers' services to some extent. Freelancing, however, involved dealing with many risks that could occur throughout the project life cycle, such as the difficulty to control freelancers and data security problems.

Motivated by the Lotus experience, Amin's strategy had been to diversify the customer portfolio by continuously adding projects from new customers. Naturally, this diversification led to some differences between the types of customers in terms of indication of project load and requirements for resources. This led to a segmentation of the resources at Arabize by customer projects, for example a dedicated team for ORACLE.

Project selection is pretty much driven by the current customer portfolio. With Oracle and SAP, Arabize gets an indication of the type of projects they will be engaged in, but the challenge is sometimes the customers' need to expedite the localization of a specific release of software that is tied to a large sale. This seems to be very common and does upset almost any plans agreed on in advance. It actually may even cause an unexpected surge in the requirements. It seems that
Arabize tries to oblige to all requests, given the competitiveness of their industry.

Arabize's major issue is getting a good indication of the required load that they can use to plan their hiring of skilled localizers. This is aggravated by the fact that it takes at least about 9 months to train someone, with good aptitude, to become a junior localizer. Since localization is more than simply translation, a good translator wouldn't necessarily be a good localizer. Most good translators tend to work as individuals. Localizers on the other hand, must work in teams on projects focused on specific products. They work within strict rules to guarantee consistent translation (consistent across different release of the product and sometimes even the product suite). It is worth noticing also that Arabize faces a challenge in finding good candidates, even if they have a good plan/forecast.

Theoretically, the use of freelancers allows Arabize to deal with sudden surges, and to balance requirements with resources. Freelancers are mainly ex-Arabizers, so they know the type of work and its requirements. In practice, however, freelancers are in limited supply, they do not have the same commitment, and sometimes do not produce the same quality. Arabize had major issues with freelancers, such as not delivering on time and even sometimes difficulties in communication and monitoring of progress. Amin and Taha started thinking about the action plan needed to eliminate the dependency on freelancers and at the same time improve the time, cost and quality performance in all Arabize localization projects.

\section{What is Next}

Improving the load forecast might be possible with better information sharing with key clients. The long lead time for preparing the required human resources and dynamic and cut-throat competition of software selling make it hard to have a reasonable forecast. Arabize may need to 
consider different options that might require structural changes. One such option is allowing for multitasking between resources, which allows more flexibility in the assignments across projects, and for risk pooling between the ups and downs of different projects loads. Another option is perhaps providing general translation services, which tend to be more on spot and short-term, to fill any unutilized valuable resources.

Amin and Taha would need to decide which options to adopt and the changes required to ensure the competitiveness and sustainability of Arabize.

\section{Acknowledgement}

The authors wish to extend their appreciation to Ms. Manal Amin, CEO of Arabize, for all her support during the course of writing this case study. Appreciation is also extended to Ms. Ebtihal Taha, Operations Director. The authors also would like to thank all the dedicated staff they interviewed at Arabize.

\section{References}

Arabize website. www.arabize.com.eg, accessed $\quad 15 \quad$ July 2012.
Asnes, M. (2009). "Localization Project Management," Presentation available from SlideShare, retrieved July 2012.

Collins, R. W. (2002). "Software Localization for Internet Software: Issues and Methods," IEEE Software, March/April 2002, pp-74-80.

Cyr, D. \& Lew, R. (2003). "Emerging Challenges in the Software Localization Industry," Thunderbird International Business Review, Vol. 45(3), May-June 2003, pp. 337358.

Microsoft

Global

Software. http://msdn.microsoft.com/enus/goglobal/bb688110.aspx, accessed 15 July

SDL.

http://www.sdl.com/technology/languagetechnology/what-is-software-

localization.html. accessed 5 July 2012.

Wikipedia.

http://en.wikipedia.org/wiki/Software_local ization 
11 The MENA Journal of Business Case Studies

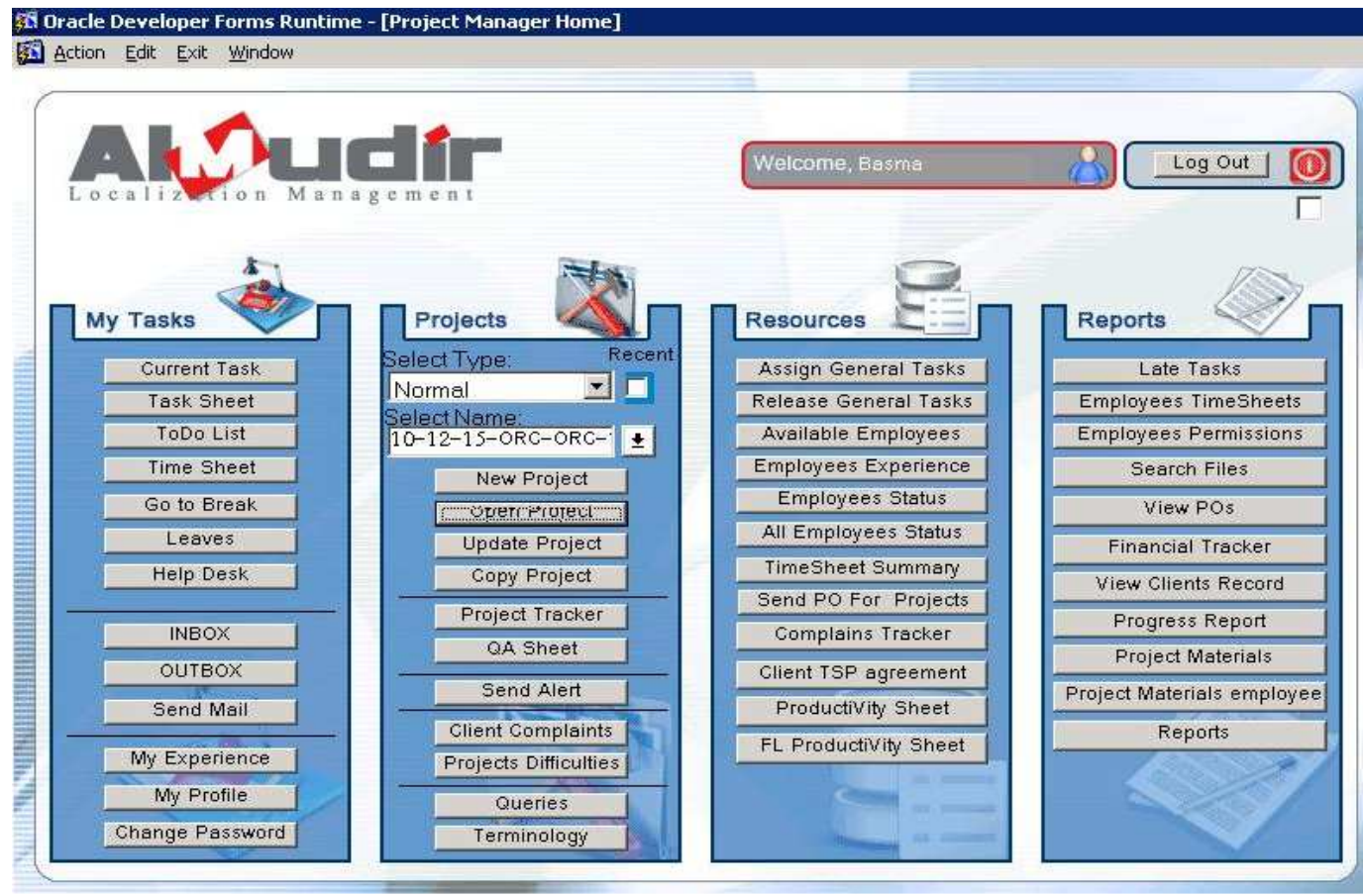

Figure 4: AlMudir Project Manager-Home

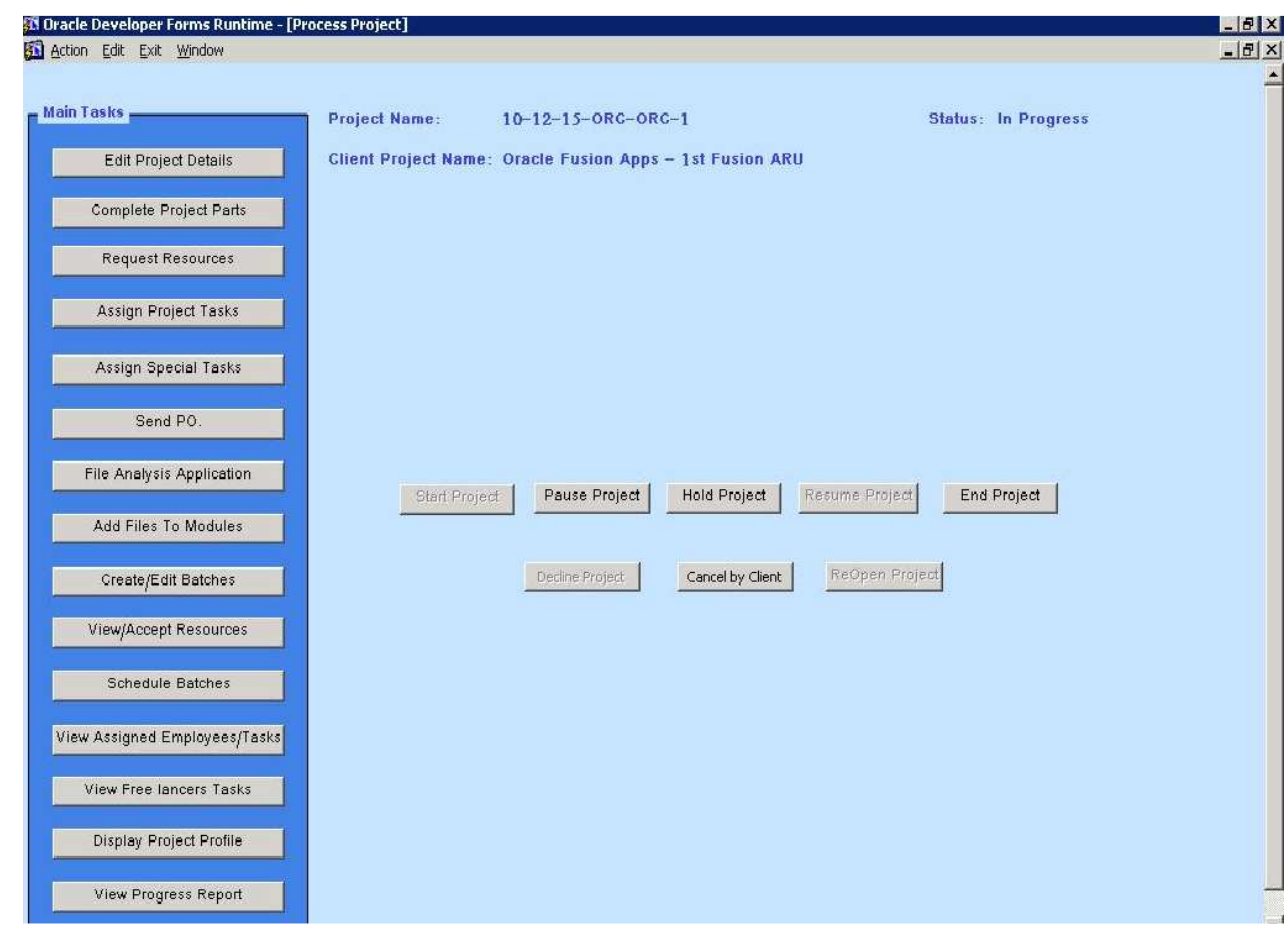

Figure 5: AlMudir Project Manager-Project 


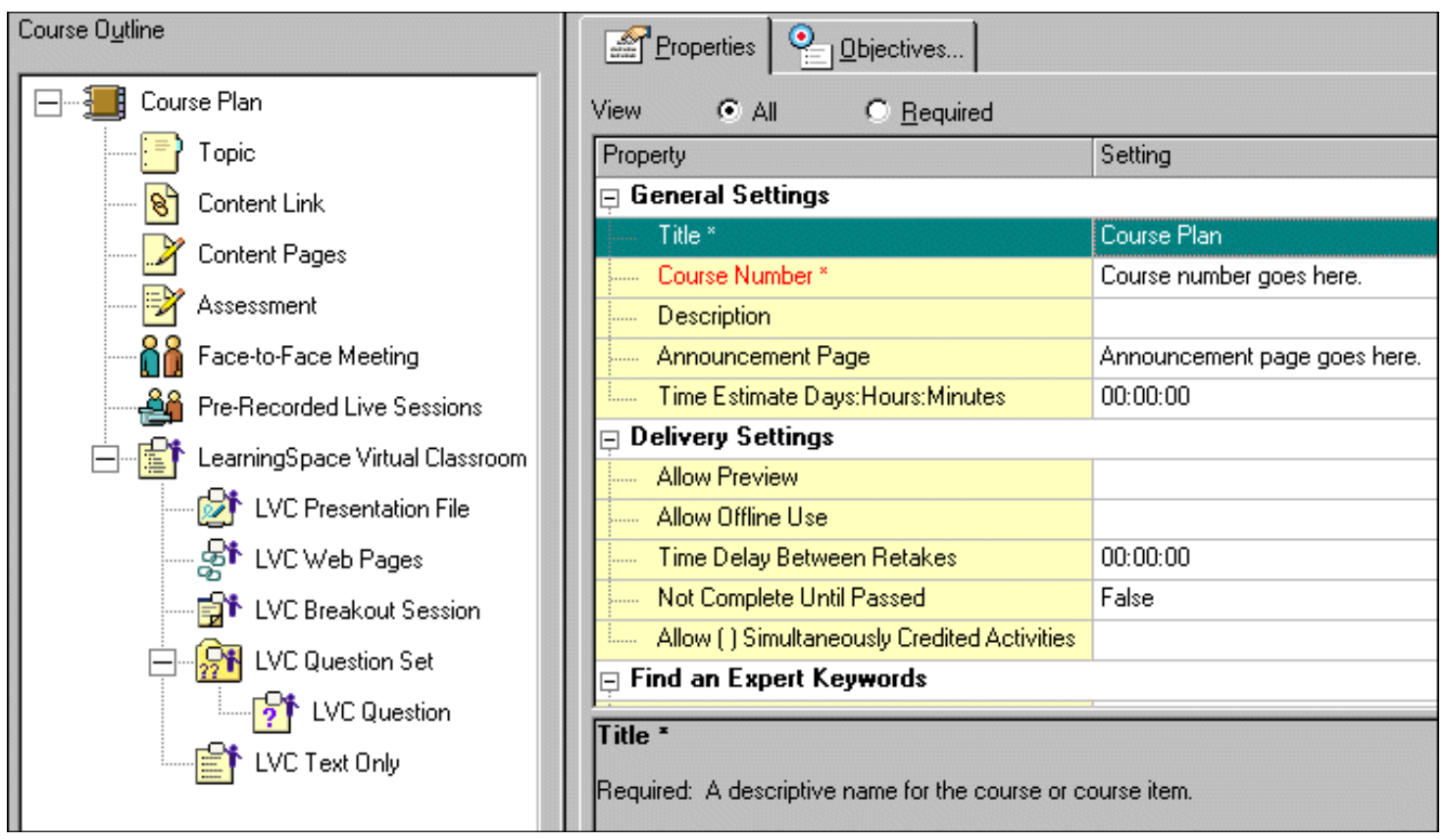

Figure 6: Before Localization to Arabic

\begin{tabular}{|c|c|c|}
\hline & 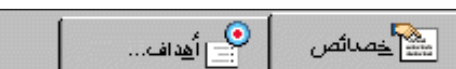 & منطظ الِيرنامج النُريبى \\
\hline & O مئلو ب & 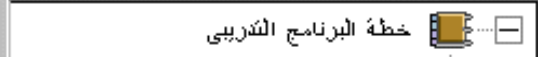 \\
\hline | إلإعداد & الذاصبية & النوضوع \\
\hline & 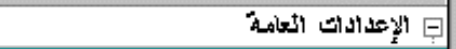 & 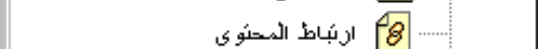 \\
\hline | خطاة البرنامج الكُريبى & العنو ان * & 28 \\
\hline موضع رئم البرنادب الكُريبي هنا. & 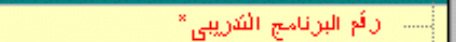 & ك الدحلو بات \\
\hline & : ل:... الوصف & 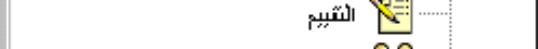 \\
\hline موضد صنفة الإعلان هنا. & |:..... صنكة الإعلان & 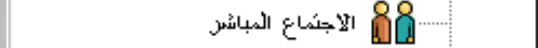 \\
\hline 00:00:00 & 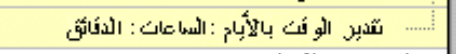 & 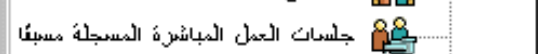 \\
\hline &  & LearningSpace Virtual Classroom \\
\hline & |: إ... السماح بالدعابنة & 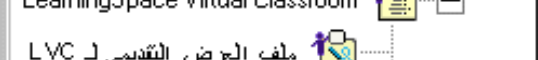 \\
\hline & 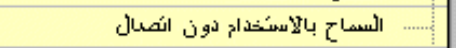 & \\
\hline 00:00:00 & : لمنزة الانظظار للإعادة & 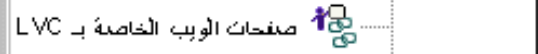 \\
\hline غبل حسبِّى & 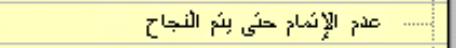 & 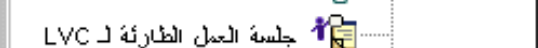 \\
\hline & 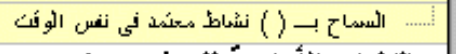 & 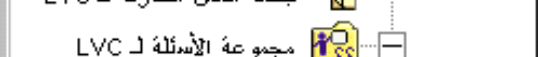 \\
\hline & 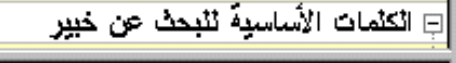 & 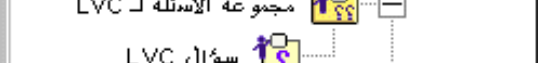 \\
\hline \multicolumn{2}{|c|}{ 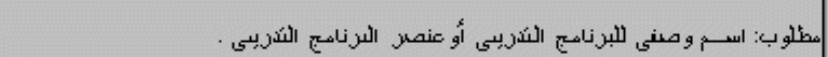 } & 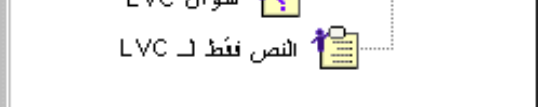 \\
\hline
\end{tabular}

Figure 7: After Localization to Arabic 